\title{
The Use of Community Language Learning Method to Increase the Students' Participation in Classroom Conversation
}

\section{Siti Nurhasanah}

sitinurhasanah270@yahoo.co.id

\begin{abstract}
Community Language Learning (CLL) is a language teaching method which involves psychological aspect and students work together to develop what skill of a language they would like to learn. This method firstly developed by Charles A. Curran and his association which is called Counseling-Learning theory. Within the language teaching tradition CLL is sometimes cited as an example of a humanistic approach. The roles of the teacher is called counselor and the learners are called client in the language classroom. The research will use Community Language Learning (CLL) method to increases the students' participation in speaking class for the students of International Class Program State Institute of Islamic Studies (IAIN) Salatiga Batch 2013/2014 Academic Year 2013. The researcher uses Classroom Action Research (CAR) who accompanied by an observer. To know the students' participation, the researcher conducts pretest and posttest within 2 cycles. Each cycle consists of planning, acting, observing and reflecting. The research shows that the students' participation increased not only their conversation but also their motivation. Based on the results and findings, the students could develop their participation which can be seen by the increasing average between pretest and posttest from the cycle 1 to the cycle 2 .
\end{abstract}

Keywords: Community Language Learning, Method, Classroom Action Research, Language, Participation 
The Use of Community Language Learning Method to Increase the Students' Participation in Classroom Conversation

\section{Abstrak}

Community Language Learning (CLL) merupakan metode pengajaran bahasa yang melibatkan aspek psikologi dimana peserta didik ikut bekerja sama dalam mengembangkan keahlian berbahasa yang ingin mereka pelajari. Metode ini pertama kali dikembangkan oleh Charles A. Curran dan asosiasinya yang disebut teori Counseling-Learning. Ada pula yang menyebut bahwa metode ini merupakan pendekatan humanisme. Pengajarnya seolah-olah bertindak sebagai konselor dan peserta didiknya sebagai klien. Selanjutnya penulis juga menggunakan metode CLL untuk meningkatkan partisipasi mahasiswa dalam kelas Speaking di Program Khusus Kelas Internasional (KKI) IAIN Salatiga Tahun Akademik 2013/2014 angkatan 2013. Penelitian yang digunakan adalah Penelitian Tindakan Kelas (PTK) dimana penulis sebagai peneliti dan ditemani oleh satu orang sebagai pengamat. Untuk mengetahui peningkatan partisipasi mahasiswa di kelas tersebut, peneliti mengadakan pretes dan postes dalam 2 siklus. Masing-masing siklus berisi perencanaan, aksi, observasi dan refleksi. Hasil penelitian menunjukkan bahwa mahasiswa mengalami peningkatan tidak hanya pada partisipasi percakapan bahasa Inggris mereka tetapi juga motivasi belajar mereka. Hal ini bisa dilihat dari peningkatan rata-rata nilai dari pretes ke postes baik di siklus 1 hingga di siklus 2.

Kata kunci: Community Language Learning, Metode, Penelitian Tindakan Kelas, Bahasa, Partisipasi

\section{Introduction}

English as the International language plays an important role in this era. It is the first international language used for international trade, tourism, education, and other important international affairs to communicate among nations in the world including students in the universities such as students of International Class Program State Institute of Islamic Studies (IAIN) Salatiga. 
International Class Program is a new program that has been established by IAIN Salatiga in October 1st, 2010. In this program, students and lectures use foreign languages including Arabic and English as the deliver language in the classroom. It means the students must be able to speak in English as their daily conversation in the classroom although they are different backgrounds from language major, natural sciences and social sciences. Another problem is the students come from different kinds of the schools such as Gontor (Islamic Boarding School), MA/ PK (Islamic Senior High School), and SMA (Senior High School).

This condition influences the speaking ability especially for students' conversation of International Class Program batch 2013. They are shy, less confident and quiet when they should speak in English both inside and outside of the classroom. At the fact, speaking is one of language skill where the students should share their ideas, thoughts, and emotions because the language indicates the ability of students to arrange the words to have conversation and discussion with their friends and lecturers. In addition it becomes challenge for the students to master foreign language especially English well. They have projection to study abroad for Master Degree or to be International teacher in the future. Therefore it is very important to them for engaging in communication by using English for the students of International Class Program.

In learning language, the most fundamental concept is psychology. According to Marion E. Bunch (1977: 3), individual instances of learning range all the way from the simplest change in behavior resulting from practice to the most complex of those in the category of the higher mental processes. 
Learning is a basic and central component of the distinctive activities that constitute the subject matter of psychology. Learning including retention, on which it depends, is at the heart of perception, thinking, imagination, reasoning, judgment, attitudes, personality traits, systems of values, and the development and organization of the activities that constitute the personality of the individual (Marion E. Bunch, 1977: 3).

To improve the ability of students in learning language, it is better to involve psychological aspects like Charles Arthur Curran did when he has taught La Forge, his student. Curran has used a method called Community Language Learning (CLL).

CLL is a method to react the sensitivity of learner for learning communicative intent. It should be noted that communicative intent is sometimes forced by the number and knowledge of learners. It has made CLL places unusual demands on teachers of language. They have to be highly fluent and sensitive to atmosphere in both L1 (Native Language) and L2 (Foreign Language).

CLL is firstly developed by Charles A. Curran and his associates. Currant is a specialist in counseling and a professor of psychology at Loyola University, Chicago, (Jack C Richards and Thedore S. Rodgers, 1986 p. 113). His application of psychological counseling techniques for learning is known as Counseling- Learning. Community Language Learning represents the use of Counseling-Learning theory to teach languages, (Jack C Richards and Thedore S. Rodgers, 1986 p. 113).

In counseling learning theory, it can be measured by performance. Learning usually related to change in stimulus-response relationships that result from practice and the evidence that learning has happened is a change in successive performances like students of International Class 
Batch 2013 should do. They have to perform drama twice in a year using foreign language Arabic and English. It is very interesting to know how CLL method will be applied to improve the students' participation in classroom conversation.

The problems and successes experienced by one or two different student groups in the classroom may not necessarily represent language learning universals. Other attentions have been expressed related to the lack of a syllabus, which makes objectives unclear, evaluation difficult to accomplish, and focus on fluency rather than accuracy, which may lead to inadequate control of the grammatical system of the target language. On the other hand, CLL emphasizes the positive benefits of a method that focus on the learner, stresses the humanistic side of language learning, and not merely its linguistic dimensions.

Because of this condition, teacher should encourage students to strive for independence. The teacher should also be culturally sensitive and prepared to redesign tile language class into more culturally compatible organizational forms. It makes the writer is interested in this method to increase the students' participation in classroom conversation for the students of International Class Program focus on batch 2013 by conducting Classroom Action Research.

\section{Research Methodology}

According to Kemmis, CAR (Classroom Action Research) is a form of self reflective enquiry undertaken by participants in social situation in order to improve the rationality and justices, their understanding of these practices and situations in which the practices are carried out (Hopkins, $1993: 44)$. 
Another definition proposed by Robert Rapport (1993) is that Classroom Action Research aims to contribute both to the practical concerns of people in an immediate problematic situation and to the goals of social science by joint collaboration within a mutually acceptable ethical framework (Hopkins, 1993 p. 44).

From the definitions above the researcher conclude that CAR as one of the form of research that tries out ideas in practice for a social situation to improve or change something and try to have a real effect on the certain situation.

\section{Research Procedure}

In this CAR, there are some steps as Kemmis stated. It consists of two cycles and each cycle has the procedures as follows:

1. Planning

Some activities in planning such as:

a. Preparing materials, making lesson-plan, and designing the steps in doing the action.

b. Preparing students' attendance list and scoring.

c. Preparing sheets for classroom observation to know the situation of teaching learning process when the method or technique is implemented.

d. Preparing a test including pretest and posttest. 


\section{Action}

Here are activities in action:

a. Giving pretest for students of International Class Program batch 2013

b. Teaching speaking (conversation) through community language learning

c. Giving chances for students to share their ideas, activities or ask any difficulties or problems

d. Asking the students some questions orally and the students answer orally related to the themes such as passion, hobby, dream, education, culture, and so on.

e. Giving posttest that will be attached in appendixes and written in lesson plan for cycle 1 and 2.

3. Observation

Observation is one of the instruments used in collecting the data. As a scientific method, observation can be systematically used to do serve and note the phenomena, investigate what students feeling, thinking, and something they do in teaching learning process. The writer plans to do this observation flexible and open to record the unexpected.

4. Reflection

After the researcher has been accomplished to analyze the observation, the researcher will plan for the next cycle. If the researcher finds problems in the first cycle, she will do better for the next cycle. 


\section{Discussions}

There are two cycles. In each cycle, the steps consist of planning, acting, observing, and reflecting.

\section{Cycle 1}

1. Planning

Before conducting the research, the researcher prepared the instruments such as:

a. Designing lesson-plan and preparing materials

Lesson plan is a teacher activities orientation so that teaching learning process can be arranged well. In the first meeting, the researcher prepares materials about passion; hobby; and interest of the students International Class Program Batch 2013. Then, the second meeting is about international events and chances.

b. Preparing students' attendance list and scoring.

c. Preparing sheets for classroom observation to know the situation of teaching learning process when the method or technique is implemented.

d. Preparing a test including pretest and post test. For pretest, the researcher uses oral test to know the students' profile of speaking skill by giving them chances to speak one by one. For post test, the researcher gives writing test. 
2. Acting

a) The Implementation of the Action 1

The researcher as the teacher and accompanied by the observer entered the class. The researcher created a good condition by asking them to make a circle and sit on the floor then the students gave attention to the teacher.

She gave the students' mind map about Community Language Learning (CLL) to give them understanding on how the study looked like and the benefits by joining this class.

After few minutes, every student introduced their names including their nicknames.

Every student gave big applause for themselves. After they have introduced themselves, they looked motivated to speak more. Then the researcher would like to see their talents. Therefore she asked them to propose three topics based on their passion, hobby, and interest.

She gave the students 15 minutes to find three topics and asked them to explain the reasons. This activity became the pretest to measure their speaking skill including pronunciation, grammar, vocabulary and fluency.

Then every student told their topics with their reasons. It was very interesting for them because most of them speak naturally and the observer wrote the topics as materials for the next meetings. She got more than 20 topics and clarified them based on the student priorities. The topics they proposed such as education, literature, writing, technology, economic, 
entrepreneurship, business, social conflict, traveling, study abroad, culture, music, art, and sport.

During their talk, the observer gave them assessments. Every student spoke about three minutes. After that, the researcher gave them comment. She also encouraged them to have no worries about mistakes when they were speaking and just be confident.

b) The Implementation of the Action 2

The next meeting the researcher greeted the students as usual. Every student in the group read and discussed the material for 15 minutes, after that they had to present their thought and feeling related to international chances. Each group told what they thought about student exchange, short course, international conference, voluntary activity, and master degree for 7 to 10 minutes.

After they got the descriptions about international programs, the researcher asked them to write their dream for 20 minutes. The writings were the expression of their feeling and thought. From this activity, the researcher made it to be posttest.

\section{Observation}

In the first cycle, the writer and the observer have observed the teaching learning process. The researcher could see that the students of ICP batch 2013 basically are motivated to speak English. However they face some problems. For example, some student can speak but the grammar is incorrect, some of them speak 
quite well but they need to improve their pronunciation, some of them have no confidence.

Sometimes some students are not ready to express their ideas when they do not have time to prepare material regarding the topic. It means some of them cannot speak naturally such as in informal situation. But they are motivated to increase their conversation through community language learning because of their dream to get international chances.

By analyzing the result of pretest and post test above, there is an increase of the students' grade of International Class Program batch 2013. It is 0.03 from 2.75 to 2.78 . This increase of the students' grade shows a little improvement of the students' participation in classroom conversation. Thus, the researcher appreciate of their effort, they already tried to improve their speaking from enough level to be good level, and from good level to be very good level.

4. Reflection

After analyzing the result of action in cycle 1, the researcher can assume that it is very important for the teacher to create comfortable condition in the classroom, it might be an informal situation but they are serious to learn and they express their ideas naturally. There is no gap among teacher and students in teaching learning process. The teacher must encourage the students before, during, and end of the class so that they are motivated to realize their dreams and express their feelings. The teacher also should appreciate what the students speak and give the students more assessment about the material and practice in speaking. 
Action 1 did not give satisfied result because the students are still less confident, shy and afraid of making mistake in grammar especially for the students of Islamic and Arabic Departments. It means that the background of their departments influences their mind.

Therefore, it is very necessary to continue the next cycle to encourage them for participating in classroom conversation. The second cycle is carried out as follow up of the first cycle. To get the effectiveness for the next cycle, the researcher will prepare better.

\section{Cycle 2}

1. Planning

Before conducting the research, the researcher prepared the instruments such as:

a. Designing lesson-plan and preparing materials

Lesson plan is a teacher activities orientation so that teaching learning process can be arranged well. In the third meeting, the researcher prepares materials about issues of international conference for the students of International Class Program Batch 2013. Then, the fourth meeting is about youth and world peace.

b. Preparing students' attendance list and scoring.

c. Preparing sheets for classroom observation to know the situation of teaching learning process when the method or technique is implemented.

d. Preparing a test including pretest and posttest. For pretest, the researcher uses oral test to know the students' profile of 
speaking skill by giving them chances to speak one by one. For posttest, the researcher gives writing test.

\section{Acting}

a. The Implementation of the Action 1

The researcher and the observer entered the class, then the researcher as well as become the teacher controlled the situation by asking them to make a circle and sit on the floor. The students give attention to the teacher.

All students laughed, actually some students were interested in to share their arguments and some of them have confidence to express their opinion but every student has spoken although some of them were active to talk and some of them did not speak. We continued to the next topic about social activity. This activity also became the assessment as pretest for the cycle 2 .

b. The Implementation of the Action 2

The researcher as the teacher greeted the students as usual. The researcher created a good condition for the students until they had paid attention to the teacher. After that, the teacher divided them in to three groups by counting 1 to 3 .

The students went to their groups and identified the problem of the topic then they tried to arrange script and practiced their roles in front of their friends. This condition also became their preparation before they perform Art and Language Exhibition (ALE) because every batch of International Class Program should perform drama twice in a year, Arabic and English drama. 
After their discussion and performance, I gave them a post test as the assessment of cycle 2 .

\section{Observation}

In the cycle 2, the researcher was accompanied by the observer observed teaching and learning process through CLL method. By monitoring the students' activities, the writer could know that the students have had high motivation to speak in English. The second cycle shows better improvement than those in the first cycle. In the second cycle, the students have more confidence and become active to discuss ASEAN Community. The researcher really appreciated of the students because they have shown big effort to improve their English.

The research showed that CLL method was appropriate to be applied for students of International Class Program batch 2013 because the relation between teacher and student like counselor and client had appeared in this activity. The teacher role was succeed to implement CLL method and the students could respond what the teacher direct to them. When the teacher proposed some topics then they could explore deeply, they felt enjoyable to express their ideas,

By analyzing the result of pretest and posttest in cycle 2, there is an increase of the students' grade of International Class Program batch 2013 at the main that has been obtained. It is 0.16 from 2.99 to 3.15. Compare to cycle 1 , the increase of mean is 0.13 from 0.03 to 0.16 . This increase of the students' grade shows an improvement of the student speaking skill. Therefore, CLL method 
is appropriate to be implemented for the students of International Class Program batch 2013 to increase the students' participation in classroom conversation. They have tried their motivation to improve their speaking, from good to be very good level.

4. Reflection

After analyzing and comparing the result of implementation between cycle I and II, the writer can say that CLL (Community Language Learning) method could increase the students' participation in the classroom conversation of the students International Class Program batch 2013. In addition, it is very important for every teacher to encourage students by giving motivation before and after the lesson. The teacher also should appreciate what every student did and spoke.

The researcher believes that every teacher has their own method but after doing Classroom Action Research (CAR) for the students of International Class Program batch 2013, CLL is appropriate to be applied for teaching and learning foreign language. Besides this method involves psychological aspect, the students have become more confident and more enjoyable to speak naturally to express their ideas, share problems, and propose questions so that this condition do not make a gap between teacher and students then they can be enjoy in learning English.

In addition, this method is one of ways to dig students' talent, encourage and appreciate what they do and speak, so that the students reach their dreams by realizing the word of International Class Program. It means CLL method which is implemented by the researcher also has had a purpose to make 
students active in classroom conversation after that the students to be more active through joining some international events and chances such as short courses, student exchanges, international conferences, voluntary activities, and study abroad for master degrees.

\section{Conclusion}

Based on the theoretical review and the implementation of the study, the writer can draw the conclusion as follows:

1. The profile of the students' participation in classroom conversation showed that generally they were quiet and less confident to speak English in the beginning of the lesson, especially for the students of non-English Department of International Class Program batch 2013. Moreover, some students could speak English but the grammars were incorrect, some of them could spoke well enough but need the improvement of pronunciations.

2. Based on the teaching and learning process by implementing Community Language Learning (CLL) method, the students could develop their participation in classroom conversation although sometimes there were grammatical errors. In addition, the students were unconfident to speak English but after using Community Language Learning (CLL) method, there were good responses from the students.

3. The result of the students' participation can be seen from the increasing average between pretest and posttest in the first cycle to the second cycle. In the first cycle, the mean of pretest is 2.75 and the mean of posttest 2.78. Then in the second cycle, the mean of pretest is 2.99 and 
the mean of posttest is 3.15. The percentage of students' participation who have gotten very good grade increase from $0 \%$ in pretest to $5.26 \%$ in posttest of the cycle 1 , and $26.32 \%$ in pretest to $42.11 \%$ in posttest of the cycle 2. From the result of the test, the writer concludes that generally CLL method could increase the students' participation in classroom conversation.

\section{References}

Richards, Jack C. 1986. Approaches and Methods in Language Teaching. New York: Cambridge University Press.

Lado Robert. 1961. Language Teaching. New York.

Branen, Julia, Mixing Methods. 1993. Qualitative and Quantitative Research. Avenbury: England.

La Forge, P.G. 1975. Research Profiles with Community Language Learning. Apple River, III.: Apple River Press.

Brown, H. Douglas. 1987. Principles of language learning and teaching. Englewood Cliffs, New Jersey, Prentice Hall

Moskowitz, G. 1978. Caring and Sharing in the Foreign Language Class. Rowley, Mass.: Newbury House.

Stevick, E.W. 1980. Teaching Languages: A Way and Ways. Rowley, Mass.: Newbury House.

Septiani, Elda. 2010. What is Community Language Learning. Accessed from http://tanpopofight.blogspot.com/2010/05/what-iscommunity-language-learning.html on Saturday at 04.05 
The Use of Community Language Learning Method to Increase the Students'

Participation in Classroom Conversation

Rhalmi, $\quad$ Mohammed. 2009. Accessed from http://www.myenglishpages.com/blog/community-languagelearning/ on Monday, March 13, 2014 at 12.09 pm

Nunan, David.1991. Language Teaching Methodology. New York: Practice Hall.

Elliot, John. 1991. Action Research for Educational Change. Buckingham, Philadelphia: Open University Press. 